\title{
Prospects of Zakat as Tax Credit in a New Normal COVID-19 Period
}

\author{
Any Setianingrum, Nurul Huda \& Perdana Wahyu Santosa \\ Universitas YARSI
}

\begin{abstract}
Previous research, regarding the prospect of zakat policy as a tax credit, was conducted using the Analytic Network Process (ANP) method, using expert respondents. To obtain findings from respondents with different backgrounds and to make it more comprehensive, this research was continued by using the SEM (Structural Equation Model) method, by filling in a questionnaire, with 235 respondents from across Indonesia. The research objective is to determine the variables that affect the preferences and participation of muzaki and taxpayers, who are willing to pay taxes and zakat, increase public finances, which can be used as a solution to the sharp a decline in aggregate economic supply and expenditure in Indonesia due to the COVID19 pandemic. The results showed that the regulatory variables, zakat incentives as tax credits, technology-based services, socialization and promotion have a significant effect on the preferences of muzaki and taxpayers. Meanwhile, regulatory variables, zakat incentives as tax credits, socialization and promotion have a significant effect on muzaki and taxpayer participation. Meanwhile, technology services and preferences in this study are not found to have a significant effect on the participation of muzaki and taxpayers. When all sectors of the commercial economy experience a decline or stagnate, the government must be able to move the philanthropic sector, so that the economy continues to run, aggregate demand and supply continues to run, and people's purchasing power is maintained, especially low-income people.
\end{abstract}

Keywords: Regulation, Incentives, Technology Services, Preferences, Participation of muzaki \& taxpayers

Jel Classification: E62, E64, H27, H89, O35

\section{INTRODUCTION}

In the current situation and conditions of the COVID-19 pandemic, almost all sectors of the global economy drop and stuck. Government spending, household and investment spending, and people's purchasing power have decreased drastically. In this condition, the philanthropic sector, especially in Indonesia, has more proven its real role and its contribution. The philanthropic sector can be the last guard so that the economy continues to run well when other sectors are stuck. So far in Indonesia, philanthropic activities originating from socio-religious donations and Corporate Social Responsibility have enormous potential, but their realization is still very small.

While the potential amount of zakat in 2011 was predicted at IDR 217 trillion, equal to $3.4 \%$ of Indonesia's 2010 GDP (Firdaus et al., 2012). However, BAZNAS Zakat Statistics shows that the actual amounts of zakat collected in the three-year period 20152018 stood at only $0.01 \%, 0.02 \%$, $0.03 \%$ and $0.05 \%$ of GDP for the three respective years (Asfarina et al., 2019). 
The government has an awareness that social welfare and public interests cannot always be fulfilled so that in many countries it tries to encourage people to be involved in philanthropic activities. The method commonly used is through the provision of tax incentives. The incentive scheme is considered capable of changing people's behaviour to carry out the activities that the government expects, because it involves rewards. This has also been proven empirically, where philanthropic activities tend to be elastic with the presence of tax incentives (List, 2011).

The advantages of tax incentives in the main philanthropic activities are that they ensure community empowerment. Apart from that, it also ensures independence as well as the collection of donated funds/goods, and ensures the availability of public funds in a fast time without the need for complex bureaucracy. The tax incentive rules for philanthropic activities basically have to balance several objectives, namely to stimulate philanthropic activities, prevent abuse of regulations, be effective and efficient in its implementation, and ultimately provide great benefits to society (Setianingrum et al., 2018).

The Indonesian government, in tackling the Covid-19 pandemic, in addition to launching various programs and state budget stimuli, is also trying to empower the philanthropic sector, especially income from the zakat sector. Some recommendations put forward to the government are, first, to provide tax incentives for zakat payers, both individuals, and companies. The second is to issue a revision of the Zakat Law number 23 of 2011 related to zakat as a deduction from taxable income to a deduction from tax payable.
Based on the description above, the tax incentive for zakat, in the form of zakat as a direct tax deduction, or zakat as a tax credit, is expected to be the next stimulus issued by the government. This needs to be encouraged by all parties to accelerate the receipt of zakat up to IDR 217 trillion, almost half of the total stimulus funds that have been issued by the government. If this zakat acceptance is realized, it is hoped that the government can postpone the policy of increasing debt for handling COVID-19.

On the other hand, based on the survey of community zakat behaviour in 2004 conducted by PIRAC, it can be seen that the majority $(50.2 \%)$ of respondents ignored zakat and in a similar survey in 2007 the number decreased to 45\% (Hendrian, 2006). This is a problem as well as a challenge that requires a solution. What policies and methods should be applied so that the receipt of zakat, as well as tax can be increased effectively.

From the other research, BAZ (Badan Amil Zakat/ amil zakat agency) in East Java shows that zakat as a subtrahend of tax has a big impact on the potential tax acceptance. Then, it can be concluded that the realization of the law of zakat and tax must be increased, not just tax only as a deduction from taxable income, as the existing regulations that apply today (Andriani \& Fathya, 2013).

Besides accommodating incentives for all types of philanthropic taxes in Indonesia, as an appreciation for citizens who have strengthened the role of the government in the welfare of society, regulatory reform is also needed (Rosdiana et al., 2019). And based on a number of previous studies, in increasing the preferences and participation of taxpayers and muzaki 
(people who are obliged to pay zakat), in addition to regulatory and incentive factors, technology-based service quality, socialization and promotion strategies must also be strengthened.

The purpose of this study is to determine the significance of the independent variables, which include independent variables: regulation, independent variables: zakat incentives as a tax credit, independent variables: technology services, independent variables: socialization and promotion, to intervening variables: preferences, and the dependent variable: participation. muzaki (who have to pay zakat) and taxpayers.

This study has a novelty compared to previous studies. In previous research, regarding strategies to increase zakat and tax income at the same time, the study of zakat as a tax credit was not associated with the influence of other variables. In this study, what is done is to examine the effect of the zakat incentive variable as a tax credit, along with the influence of other variables, on the participation rate of muzaki and taxpayers. Other variables that affect the level of participation, apart from incentives, will also examine the influence of regulatory variables, technology-based services, socialization and promotion, and preferences.

Another novelty is that this study uses primary data, through questionnaires to 235 respondents randomly, using the SEM (Structural Equation Model) method. Whereas in previous research, which researchers have conducted, used the ANP (Analytic Network Process) method, using expert-based respondents (Setianingrum et al., 2019). So it is hoped that the two different studies in terms of the segment of respondents, one based on experts, and the second based on random respondents, will find more comprehensive and complementary findings.

The limitation of this study is that the number of respondents is still minimal due to cost and time constraints. Supposedly to achieve an ideal normal distribution, the number must be far more than 235, given the large population of muzaki and taxpayers in Indonesia.

\section{LITERATURE REVIEW}

The following is a literature review, which presents a number of previous studies, to determine the position of this research. The policy in Malaysia, Zakat is used as a fiscal policy tool, whereby income taxpayers are given a 100 percent discount, from the zakat they pay. The results of research conducted using state panel data in Peninsular Malaysia, it is found that zakat has a positive and significant effect on tax revenue. A study to explore the factors that influence the perception of Muslim consumers on tax cuts through zakat in Malaysia found that the halal-haram aspect of Islamic sharia has a very positive influence on the perception of Muslim consumers on the tax discount system. In addition, legal awareness and knowledge of taxes and zakat have a significant positive effect on Muslim consumer perceptions of this system (Al-Mamun \& Haque, 2015).

The extraordinary development of China's nonprofit sector also treats the tax incentives on donations, with all the advantages and disadvantages of their current system. A comprehensive tax transplant effort from valuable ideas and practices, though bold and inconvenient to host countries at first, is what China needs to build a strong non- 
profit sector (Hu, 2015). Globally, some form of tax incentive is offered to corporate donors in $77 \%$ of nations whilst some form of incentive is offered by governments to encourage individual giving in $66 \%$ of countries (where the corporation and personal income taxes are imposed). This clearly demonstrates a global consensus that charitable activity is beneficial to society.

In other research results, which aim to test and provide empirical evidence, regarding the efficiency of corporate income tax, the Pt Alwan Zahira 2010 case study, before and after the application of zakat, shows the positive role of zakat in tax planning. The results of the calculation of corporate income tax, by applying zakat as tax planning are more efficient than without the application of zakat as tax planning (Cahyono \& Putri, 2012).

In a previous research result, it shows that zakat as a deduction from income tax has a greater effect than zakat if is treated as only a deduction for taxable income. Zakat as a deduction from income tax will increase the impact of zakat on the larger economy (Djatmiko, 2019). Based on the study, the results of the previous studies above show that there is a positive effect, from the integration of zakat and tax policies, on income in both sectors.

\section{RESEARCH METHODOLOGY}

The method of this study is Structural Equation Modeling (SEM). SEM is a multivariate statistical analysis technique that is used to analyze structural relationships. This method is the mix of factor analysis and multiple regression analysis, and it is employed to analyze the structural relationship between measured variables and latent constructs. In this method, respondents fill out a questionnaire, based on their perceptions on regulatory variables, incentives, services based on technology, promotion and socialization, preferences and participation.

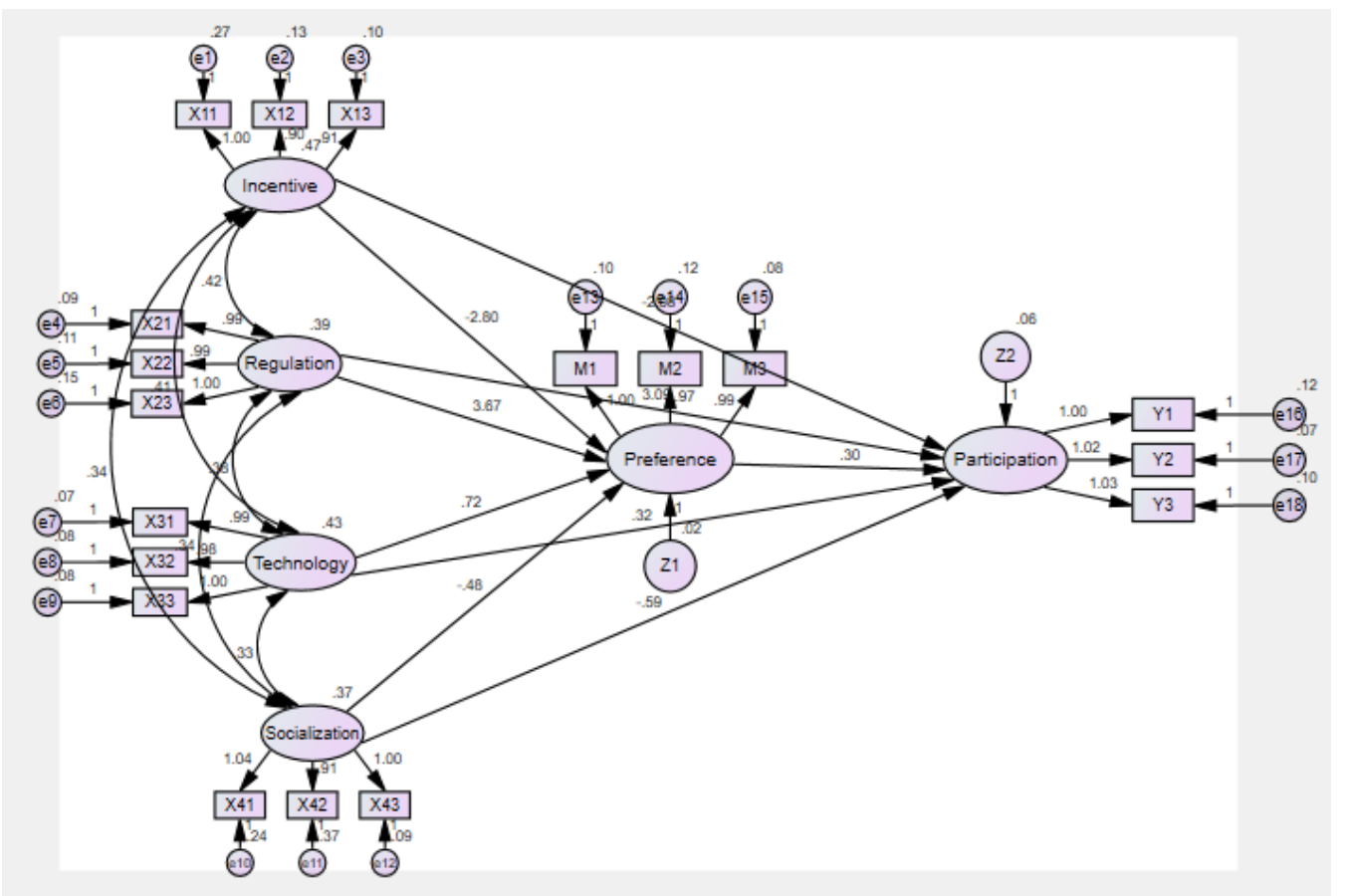

Figure 1. SEM Model Diagram 


\section{Sem Model Diagram}

The theoretical model that has been built will be depicted in a SEM model diagram which will make it easier to see the causal relationships to be tested. In this diagram, the relationships between the constructs will be represented by arrows. Straight arrows indicate a direct causal relationship between one construct and another. Meanwhile, the curved lines between the constructs with arrows at each end indicate the correlation between the constructs. The AMOS model image can be seen in Figure 1.

\section{CFA Test (Confirmatory Factor Analysis)}

In the SEM method, the first thing to do is the CFA test, which is used to reduce indicators on research variables. The indicators used to measure the research variables are those that have a $p$-value $<0.05$ and a loading factor $>0.5$. Meanwhile, indicators that have a $\mathrm{p}$ value $>0.05$ and a loading factor $<0.5$ are eliminated from the model. The CFA test uses the AMOS program, this test is carried out on a full structural model. In the Regression Weight output, at the P-value (Probability), if the value is not significant (above 0.05) then the indicator must be removed (Ghazali, 2014). And in the Standardized Regression Weight, the loading factor (Estimate) value above 0.5 indicates that this indicator can explain the existing construct (Santoso, 2015).

\section{SEM Model Testing on Amos}

SEM model analysis consists of several stages, including:

\section{Data Normality Test}

One of the assumptions of using parametric statistics is the assumption of multivariate normality. The normality test is carried out to see the level of normality of the data used, whether the data is normally distributed or not. Whether or not the data distribution is normal can be seen from the critical ratio (CR) value on skewness and kurtosis. The comparison value for $C R$ is the $Z$ number. In general, the $99 \%$ confidence level is used, at this level of confidence the significance level is 0.01 or $1 \%$, the $\mathrm{Z}$ number is 2.58 . Thus a data distribution is said to be normal if the cr skewness number or the cr kurtosis number is between -2.58 to 2.58. However, if these numbers are below -2.58 (eg $-4,-5$ etc.) or above 2.58 , the data distribution can be said to be abnormal (Santoso, 2015).

\section{Outlier Test}

Outliers are observations that appear with extreme values both univariate and multivariate. Outliers arise because of their unique combination of characteristics and appear very different from other observations. Looking at the output data in this study through the Mahalanobis d-squared output. According to (Ghazali, 2014), to see the outliers data is to compare the Mahalanobis distance value with the Chi-square table at a significance of 0.001, the Mahalonobis d-squared value that is greater than the Chi-square table is indicated by outlier data. The value of the Chi-square table is sought at a significance of 0.001 with DF (the number of variable indicators in the full model image).

\section{Multicollinearity Test}

The multicollinearity test aims to see the strong influence between the 
independent (exogenous) variables. Multicollinearity can be seen through the determinant of the covariance matrix. The very small determinant value indicates the presence of multicollinearity and singular problems (Ghazali, 2014). It is expected that the determinant value will stay away from 0 and better if it is more than 1 .

\section{Goodness of Fit Test (Model Feasibility Test)}

The Goodness of fit test is used to find out how precisely the manifest variables (indicator variables) can explain the latent variables (constructs) that exist. Overall Goodness of fit can be assessed based on a minimum of 5 criteria. In empirical research, a researcher is not required to meet all the goodness of fit criteria, but it depends on the judgment or decision of each researcher.

\section{Reliability Test}

Reliability is a measure of the internal consistency of the indicators of a formation variable that shows the degree to which each indicator indicates a commonly formed variable. There are 2 reliability tests, namely Composite (Construct) reliability and Variance extracted. The cut-off value of Construct reliability is at least 0.70 while the Variance extracted is at least 0.50 (Ghazali, 2014).

\section{Hypothesis Testing (Influence between Variables)}

Hypothesis formulation:

H1: Incentives affect preferences

$\mathrm{H} 2$ : Regulation affects preferences

H3: Technology affects preferences

H4: Promotion affects preferences

H5: Incentives affect participation

H6: Regulation affects participation

H7: Perception affects participation

H8: Technology affects participation
H9: Promotion affects participation

The basis for decision making (Santoso, 2015):

- If the value of $\mathrm{P}$ (Probability)> 0.05 then $\mathrm{HO}$ is accepted (No influence)

- If the P-value (Probalitias) $<0.05$ then $\mathrm{HO}$ is rejected (There is an effect)

The term limits in this study are as follows: First, perception is the brain's ability to translate a stimulus or process to translate the stimulus that enters the human sense organs. Every individual has a tendency to see the same object in different (Bachtiar, 2006). In this study, the perceptions in question are perceptions of incentives zakat as a tax credit, perception of regulation, perceptions of services based on technology, perceptions of promotion \& socialization, perception of participation. Second, preference is the customer values obtained in determining a choice, namely an assessment of the best desires of consumers. Third, muzaki participation is the stage in the decision-making process where the muzaki actually chooses. Decision making is an individual activity that is directly involved in obtaining and using the services offered. Muzaki is a person or body owned by a Muslim who is obliged to pay zakat.

\section{FINDINGS}

\section{Respondent Profile}

In this study, the sample was randomly distributed to the community, regardless of domicile, age, education, gender, and income level. Data collection and questionnaire filling by respondents were carried out in June 2020. The 
following is an overview of the Respondent's profile:

The total number of respondents was 235 people, consisting of $62.6 \%$ male and $37.4 \%$ female. The age of the respondents is 20 years and over, and the majority are 25 to 30 years old. As many as $59.6 \%$ of respondents have postgraduate education, $32.8 \%$ have undergraduate education, the rest are high school, D1, D3 or equivalent. The majority of respondents as much as 98.7\% are Muslim. The respondent's domicile is $63.4 \%$ in Jabotabek, $14 \%$ outside Java Island, $10.2 \%$ in West Java, the rest is East Java. Respondents' occupations consisted of $31.1 \%$ teachers, $25.1 \%$ lecturers, the rest were civil servants, BUMN employees, entrepreneurs/entrepreneurs, and others. As many as $46.4 \%$ of the respondents earned less than Rp. 10 million, $17 \%$ of the respondents had Rp. 10 million to Rp. 15 million, and the rest above Rp. 15 million.
As many as $80.9 \%$ of respondents admitted that they regularly pay taxes and zakat. $14 \%$ of respondents admit to only paying zakat, and the rest admit to paying only taxes. The place for zakat distribution of respondents consisted of $35.7 \%$ of respondents claiming to pay through BAZNAS (National Zakat Agency), $22.1 \%$ directly to mustahik, $18.7 \%$ through amil zakat of the nearest mosque, $11.1 \%$ through LAZ (Lembaga Amil Zakat) where they work, and the rest are fickle and impermanent. As many as $68.5 \%$ of respondents stated that they had heard about the policy, in which zakat as a direct tax deduction, is applied in Malaysia.

\section{Goodness of Fit Test}

The purpose of testing the fit model or Goodness of fit is to determine whether the model formed is fit or not, namely whether the manifest variables (indicator variables) can explain the existing latent variables. The output results are as follows:

Figure 2. Model Fit Summary

\begin{tabular}{llll}
\hline Goodness of Fit & Cut off value & Hasil & Keputusan \\
\hline Probabilitas Chi Square & $\geq 0,05$ & 0,000 & Bad Fit \\
\hline CMIN/DF & $\leq 2,00$ & 1,830 & Good Fit \\
\hline GFI & $\geq 0,90$ & 0,903 & Good Fit \\
\hline AGFI & $\geq 0,90$ & 0,862 & Marginal Fit \\
\hline CFI & $\geq 0,90$ & 0,977 & Good Fit \\
\hline TLI & $\geq 0,90$ & 0,970 & Good Fit \\
\hline NFI & $\geq 0,90$ & 0,951 & Good Fit \\
\hline IFI & $\geq 0,90$ & 0,977 & Good Fit \\
\hline RMSEA & $\leq 0,08$ & 0,062 & Good Fit \\
\hline RMR & $\leq 0,05$ & 0,015 & Good Fit
\end{tabular}

Based on the table above, it can be seen that there are at least 5 indicators that are Good fit (there are 8 that are Good fit), so it can be concluded that the overall model is fit. Overall Goodness of fit can be assessed based on a minimum of 5 criteria. In empirical research, a researcher is not required to meet all the goodness of fit criteria, but it depends on the judgment or decision of each researcher (Ghazali, 2014). 


\section{HYPOTHESIS TEST (ANALYSIS OF INTER-VARIABLE INFLUENCE) BOOTSTRAP METHOD}

After overall a structural model can be considered fit, the next process is to see whether there is a significant influence between the independent variable and the dependent variable. The output results can be seen on attachment 9 .

The Basis for decision making: (Santoso, 2015: 150)

- If the value of P (Probability)> 0.05 then $\mathrm{HO}$ is accepted (No influence)

- If the P-value (Probalitias) $<0.05$ then $\mathrm{H} 0$ is rejected (There is an effect)

Conclusion:

1. Incentives affect preferences. This is because the probability value is less than $0.05(0.000<0.05)$

2. Regulation affects preferences. This is because the Probability value is less than $0.05(0.000<0.05)$

3. Technology services affect preferences. This is because the probability value is less than 0.05 $(0.003<0.05)$

4. Promotion/socialization affects preferences. This is because the probability value is less than 0.05 $(0.026<0.05)$

5. Incentives affect participation. This is because the probability value is less than $0.05(0.004<0.05)$

6. Regulation affects participation. This is because the probability value is less than $0.05(0.000<0.05)$

7. Preferences has no effect on participation. This is because the probability value is more than 0.05 $(0.586>0.05)$

8. Technology services has no effect on participation. This is because the probability value is more than 0.05 $(0.093>0.05)$
9. Promotion affects participation. This is because the probability value is less than $0.05(0.002<0.05)$

The results of this study indicate that incentives have a significant effect on the preferences and participation of muzaki and taxpayers. These findings are in line with the results of research which states that, the best way to recover the role of private charity is through a charity tax credit, implemented initially at the state level. Its aim is simple: to give citizens greater control over their tax dollars by allowing them to claim a credit against their personal income tax liability for contributions made to charitable organizations that assist the poor. The ideal plan is a charity tax credit that is budget-neutral--that is, one in which public spending is reduced by the same amount credited to taxpayers. This would ensure that resources are transferred from ineffective government programs to private charities that successfully reclaim lives (Barwick et al., 1998). These findings are also in line with the results of previous studies which concluded that, there is a diversity of commitments and obligations for compliance behaviour on zakat donation. Amongst the universal themes of zakat paying motivations namely: tax repayment incentive (Farah et al., 2019).

The regulatory variable in this study proved to have a significant effect on the preference variable and the participation of muzaki and taxpayers. These results are in line with the results of the research which states that procedural justice has a positive and significant effect on taxpayer compliance (Dewi \& Purwanto, 2015).

Based on the results of hypothesis testing, variable of service based on technology is proven to have 
an effect on the preference variables of muzaki and taxpayers. Other research results also corroborate these findings, which confirms that the quality of tax services, by the tax authorities, has a positive and significant effect on tax compliance (Dewi \& Purwanto, 2015).

In this study, the variable promotion and/or socialization of knowledge and awareness, on zakat policy as tax credit, is also proven to have a significant effect on the preference and participation variables of muzaki and taxpayers. These results are supported by the results of research which states that there is an effect of knowledge and perceptions on tax compliance at KPP Pratama Pamekasan. Tax Amnesty, Sanctions, Examination, Awareness, Knowledge, Perception, and Services simultaneously and significantly affect tax compliance at KPP Pratama Pamekasan ((Ra'ana, Mahmud, 1997)(Famami, 2019).

A number of previous research results strengthen the findings of this study, that the variable perception: regulation, service, and promotion as well as the socialization of knowledge and awareness, has a significant effect on the preferences of muzaki and taxpayers. The previous studies are as follows: Service quality has a positive effect on willingness to pay taxes (Hardiningsih \& Yulianawati, 2011).

On another previous result, a good perception of the effectiveness of the taxation system, in other words, related to regulations, as well as knowledge and understanding of tax regulations, partially affects the compliance of paying MSMEs taxes in Kendal Regency. This means that the Tax Service Office must be more intensive in disseminating Government Regulations to the public, especially MSME owners in order to encourage
MSME owners to pay taxes (Fahluzy \& Agustina, 2014). This also occurs at the Gianyar Tax Office Primary, the results of the study show that knowledge and understanding of tax amnesty regulations, and a good perception of the effectiveness of the tax amnesty system have a positive effect on the willingness of taxpayers to become tax amnesty participants (Yani \& Noviari, 2017).

Another common thread is, the integration of tax and zakat is expected to increase the honesty of muzakki, as well as taxpayers in conducting their own assessments. This is supported by the results of research which show that Islamic accounting financial reports, when viewed from the point of view, are very different from tax accounting, but in terms of meaning and integrity, Islamic accounting and tax accounting financial reports have several similarities, both of which require unconditional honesty (Ritonga, 2016).

However, until now, the synergy of taxation and zakat in Indonesia is only part of the statutory regulations, there is no other scheme that can be applied. There has been no collaboration between BAZNAS as the official national amil zakat body, with the government through the Taxation Directorate. So that the cooperation is not optimal. Especially in program programs such as counseling, promotion, information in the mass media, as well as in increasing zakat targets and tax revenues, benefits and increasing zakat and tax revenues are not optimal (Hasan, 2018).

Although the government has issued Government Regulation No.60 of 2010, which states that zakat and / or other compulsory religious contributions, can be deducted from taxable income, so that there is no 
double burden for Muslims. However, zakat management in Indonesia has not provided optimal results, both in the collection and empowerment of zakat fund (Ma'mun, 2017).

When comparing the current zakat regulations in Indonesia, with the government's duties and obligations regarding zakat, according to Yusuf Qadrawi, it appears that there are still many aspects of zakat management that the government has not touched on. Yusuf Al Qardhawi explained that it is the government who is responsible for collecting zakat in the country(Ramadhan, 2017).

Based on all the results of this and previous research, it can be concluded that the preferences of muzaki and taxpayers are more prospectively enhanced by the support of zakat incentives as tax credit, regulation, technology services, promotion and socialization. And the participation of muzaki and taxpayers can be increased with the support of zakat incentives as tax credit, regulation, promotion and socialization. Meanwhile, technology services and preferences in this study do not have a significant effect on the participation of muzaki and taxpayers.

Based on the description above, in general it can be concluded that, the philanthropic sector has an equally important role, with the commercial sector in driving the wheels of the people's economy. The philanthropic sector can be the last line of defence in maintaining people's purchasing power, especially the lower middle class, which will encourage production and distribution of goods and services. In the end, the upper middle class, as owners of the factors of production, will also be helped, because people's purchasing power increases, they can continue to produce. The contribution of the philanthropic sector in almost all countries, including Indonesia, was proven when almost all commercial economic sectors experienced negative growth during the COVID-19 pandemic period.

\section{CONCLUSIONS}

Regulatory variables, zakat incentives as tax credits, technology-based services, socialization and promotion have a significant effect on the preferences of muzaki and taxpayers. On the other hand, regulatory variables, zakat incentives as tax credits, socialization and promotion have a significant effect on muzaki and taxpayer participation. Meanwhile, technology services and preferences in this study do not have a significant effect on the participation of muzaki and taxpayers.

Other meanings of the findings are, that the preferences of muzaki and taxpayers will be more prospective to be increased, with regulatory support, zakat incentives such as tax credits, technology-based services, promotion and outreach. And the participation of muzaki and taxpayers can also be increased with the support of zakat incentives as tax credit, regulation, promotion and socialization. Or in other words, regulatory support, zakat incentives as tax credits, technologybased services, as well as promotion and outreach activities will strengthen the preferences of muzaki and taxpayers, to fulfil both obligations at once. Regulatory support, incentives, outreach and promotion will also increase the amount of zakat and tax revenue at the same time, as well as increase the base of muzaki and taxpayers. 


\section{RESEARCH IMPLICATION}

Amid worsening economic conditions, due to the COVID-19 pandemic, the government must remain steadfast in realizing an independent $\mathrm{APBN}$, and reduce foreign debt as hard as possible, among others by implementing a zakattax integration policy, as a main solution. The integration of tax zakat will be a source of data, as a means of information about the actual income, so that it becomes a basis for building a database of muzaki and taxpayers, as well as of course mustahik data (people who are entitled to zakat), with the support of existing technological advances. The government synergizes with existing zakat institutions, human resources and zakat activists, must build public trust to distribute zakat through LAZ, because based on the respondent profile of this study, there are still many Muslim communities channelling their zakat directly to mustahik. An easy and straightforward procedure for claiming the amount of zakat as a tax deduction is made. Further research is needed, regarding regulatory reform, as well as applications, which can be accessed by all Indonesian citizens, to find out in real time the amount of zakat collected and its distribution in detail for the trust of the people.

\section{REFERENCES}

Ahmad, S., Nor, N. G., \& Daud, Z. (2011). Tax-based modeling of zakat compliance. Jurnal Ekonomi Malaysia.

Al-Mamun, A., \& Haque, A. (2015). Tax Deduction Through Zakat: An Empirical Investigation On Muslim In Malaysia. Share: Jurnal Ekonomi Dan Keuangan Islam. https://doi.org/10.22373/share.v4i
2.1027

Ali Muktiyanto Hendrian. (2006). Zakat sebagai pengurang pajak. Zakat Sebagai Pengurang Pajak.

Alma, B. (2014). Managemen Pemasaran dan Pemasaran Jasa. Alfabeta.

Aris Tri Cahyono \& Erdania Eka Putri. (2012). Penerapan Zakat Sebagai Perencanaan Pajak Untuk Efisiensi Pph Badan Pada Pt Alwan Zahira Samarinda. Jurnal Eksis.

Asfarina, M., Ascarya, A., \& Beik, I. S. (2019). Re-Estimating The Zakat Potential In Indonesia Based On Classical And Contemporary Fiqh Approaches. Journal of Islamic Monetary Economics and Finance. https://doi.org/10.21098/jimf.v5i2 .1068

Bachtiar, W. (2006). Classical Sociology. PT. Remaja Rosdakarya.

Barwick, P. S., Matthews, M., Rector, R., Arnett, G.-M., \& CarlsonThies, S. W. (1998). Charity Tax Credits--And Debits. Policy Review.

Dewi, A., \& Purwanto, N. A. (2015). Faktor-Faktor yang Mempengaruhi Wajib Pajak Orang Pribadi. Diponegoro Journal of Accounting.

Djatmiko, H. (2019). Re-formulation zakat system as tax reduction in Indonesia. Indonesian Journal of Islam and Muslim Societies. https://doi.org/10.18326/ijims.v9i 1.135-162

Famami, A. H. (2019). Faktor-Faktor Yang Mempengaruhi Kepatuhan Wajib Pajak Di Kpp Pratama Pamekasan. Jurnal Akademi Akuntansi. https://doi.org/10.22219/jaa.v2i2. 10438 
Farah, J. M. S., Shafiai, M. H. B. M., \& Ismail, A. G. B. (2019). Compliance behaviour on Zakat donation: A qualitative approach. IOP Conference Series: Materials Science and Engineering. https://doi.org/10.1088/1757899X/572/1/012040

Firdaus, M., Beik, I.S., Irawan, T., Juanda, B. (2012). Economic Estimation and Determinations of Zakat Potential in Indonesia (WP\#1433-07.).

Ghazali, I. (2014). Model Persamaan Struktural Konsep dan Aplikasi dengan Program Amos 22 (VI). Badan Penerbit Universitas Diponegoro.

Hardiningsih, P., \& Yulianawati, N. (2011). Faktor-Faktor Yang Mempengaruhi Kemauan Membayar Pajak. Dinamika Keuangan Dan Perbankan. https://doi.org/ISSN: 1979-4878

Haryono, S. (2017). Metode sem untuk penelitian manajemen Amos lisrel PLS. Luxima Metro Media.

Hasan, N. I. (2018). Tinjauan Penerapan Pungutan Pajak dan Zakat Menurut Konsep Ekonomi Islam di Indonesia. ISLAMADINA. https://doi.org/10.30595/islamadin a.v19i2.2628

Hu, T. (2015). An Egg vs. An orange: A comparative study of tax treatments of nonprofit organizations. Frontiers of Law in China. https://doi.org/10.3868/s050-004015-0010-4

List, J. A. (2011). The market for charitable giving. Journal of Economic Perspectives. https://doi.org/10.1257/jep.25.2.1 57

Ma'mun, M. T. (2017). Prospek Penerapan Zakat Pengurang Pajak Penghasilan Sebagai Alternatif
Kebijakan Fiskal Di IndonesiA. Jurnal Riset Manajemen Dan Bisnis (JRMB) Fakultas Ekonomi UNIAT.

https://doi.org/10.36226/jrmb.v2is 1.53

Quick, E., Kruse, A. T., \& Pickering, A. (2013). Rules to Give ByA Global Philanthropy Legal Environment Index.

Ra'ana, Mahmud, I. (1997). Ekonomi Pemerintahan Umar Ibn alKhatab (3rd ed.). Pustaka Firdaus.

Ramadhan, M. R. (2017). Integrasi Pajak Dan Zakat Di Indonesia. Islamiconomic: Jurnal Ekonomi Islam. https://doi.org/10.32678/ijei.v8i1. 54

Ritonga, R. (2016). Keterkaitan Laporan Keuangan Akuntansi Syari'ah dengan Laporan Keuangan Akuntansi Pajak. Human Falah.

Rosdiana, H., Murwendah, M., \& Inayati, I. (2019). Tax Incentives For Indonesian Philanthropy: The Balance Of Effectiveness Of Pull Factor And The Role Of The State. Al-Iqtishad: Jurnal Ilmu Ekonomi Syariah. https://doi.org/10.15408/aiq.v11i2 .11240

Santoso, S. (2015). SPSS20 Pengolahan Data Statistik di Era Informasi. PT. Alex Media Komputindo, Kelompok Gramedia.

Setianingrum, A., Fadhilah, P. R., \& Rusydiana, A. S. (2019). Zakat as a Tax Credit for Raising Indonesian Tax Revenue. International Journal of Zakat.

Setianingrum, A., Madjid, S., \& Asaari, M. (2018). Zakat As Tax Credit For Harmonize Fiscal Setting In Indonesia. Jurnal Ekonomi Pembangunan. https://doi.org/10.22219/jep.v16i1 
.8200

Simamora, B. (2003). Consumer Behavior Research Guide. PT Gramedia Pustaka Utama.

Tjiptono, F. (2007). Prinsip-Prinsip Total Quality Service. Andi Offset.

Wasilah, G. A., \& Tambunan, M. R. U. D. (2019). Tax Incentive Policy Evaluation on Donation for Disaster Charity in Indonesia. MIMBAR: Jurnal Sosial Dan Pembangunan.

https://doi.org/10.29313/mimbar.v $35 \mathrm{i} 2.5020$

Yani, D. A., \& Noviari, N. (2017). Faktor -Faktor Yang Mempengaruhi Kemauan Wajib Pajak Menjadi Peserta Amnesti PajaK. E-Jurnal Akuntansi, 20(1).

Any Setianingrum

Universitas YARSI

anysetianingrum@yahoo.com

Nurul Huda

Universitas YARSI

Perdana Wahyu Santosa

Universitas YARSI 
